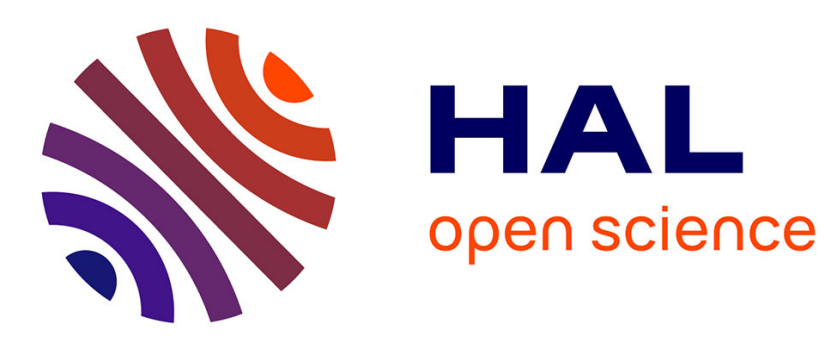

\title{
Hypomyelinating leukodystrophies in adults
}

Fanny Mochel

\section{To cite this version:}

Fanny Mochel. Hypomyelinating leukodystrophies in adults. European Journal of Neurology, In press, 10.1111/ene.14694 . hal-03119875

\section{HAL Id: hal-03119875 \\ https://hal.sorbonne-universite.fr/hal-03119875}

Submitted on 25 Jan 2021

HAL is a multi-disciplinary open access archive for the deposit and dissemination of scientific research documents, whether they are published or not. The documents may come from teaching and research institutions in France or abroad, or from public or private research centers.
L'archive ouverte pluridisciplinaire HAL, est destinée au dépôt et à la diffusion de documents scientifiques de niveau recherche, publiés ou non, émanant des établissements d'enseignement et de recherche français ou étrangers, des laboratoires publics ou privés. 


\section{european journal of neurology the official journal of the european academy of neurology}

\section{Hypomyelinating leukodystrophies in adults}

\begin{tabular}{|r|l|}
\hline Journal: & European Journal of Neurology \\
\hline Manuscript ID & EJoN-20-2927 \\
\hline Wiley - Manuscript type: & Editorials \\
\hline Date Submitted by the \\
Author: & $15-$ Dec-2020 \\
\hline Complete List of Authors: & Mochel, Fanny; CNRS UMR 7225, Sorbonne Universités, Inserm U 1127 \\
\hline Keywords: & $\begin{array}{l}\text { Leukodystrophies < Genetic and inherited disorders < NEUROLOGICAL } \\
\text { DISORDERS, Multiple sclerosis < Demyelinating diseases < } \\
\text { NEUROLOGICAL DISORDERS, hypomyelination }\end{array}$ \\
\hline
\end{tabular}




\section{Hypomyelinating leukodystrophies in adults}

Fanny Mochel ${ }^{1,2}, \mathrm{MD}, \mathrm{PhD}$

1. AP-HP, Pitié-Salpêtrière University Hospital, Department of Genetics, Reference Centers for Adult Neurometabolic diseases and Adult Leukodystrophies, F-75013, Paris, France.

2. INSERM U 1127, CNRS UMR 7225, Sorbonne Universités, UPMC Univ Paris 06 UMR S 1127, Institut du Cerveau et de la Moelle épinière, ICM, F-75013, Paris, France.

Count: Text: 774 words: References: 8.

\section{Conflict of interest: none.}

Leukodystrophies - i.e. genetic diseases primarily affecting the CNS white matter (WM) - are increasingly recognized in the field of adult neurology. Thanks to greater access to next generation sequencing (NGS) such as gene panels, whole-exome or whole-genome sequencing, many rare disorders classically affecting the WM in children are now diagnosed in adults. MRI of the CNS remains a key diagnostic tool for leukodystrophies ${ }^{1}$, including for differential diagnoses with acquired vascular leukoencephalopathies or inflammatory leukoencephalopathies ${ }^{2}$, e.g. multiple sclerosis (MS). The so-called demyelinating, and most common, leukodystrophies are characterized by prominent WM T2-hyperintensity and T1-hypointensity, usually symmetrical and confluent, unlike MS. Conversely, hypomyelinating leukodystrophies present with mild WM T2-hyperintensity associated with almost normal T1 signal. The recognition of such rare pattern of WM abnormalities is more challenging for neurologists and neuroradiologists. Hence, the diagnosis of hypomyelinating leukodystrophies is often overlooked in adult medicine.

To address this gap, Di Bella et al. reported on 25 adult patients classified with a pattern of hypomyelination on brain MRI ${ }^{3}$. A gene panel including 142 genes associated with genetic leukoencephalopathies identified pathogenic variants in genes associated with hypomyelinating leukodystrophies (PLP1, GJC2, GJA1, TUBB4A, POLR3A, POLR1C, RARS1) in 8 patients, and likely pathogenic variants in genes encoding peroxisomal proteins (PEX3, PEX13) in 2 patients ${ }^{3}$. Accordingly, the diagnostic yield in this series was $40 \%$. In one patient, 2 variants of unknown significance were also identified in $T B C D$, a gene recently associated with a severe leukoencephalopathy in children ${ }^{3}$; however, this finding requires further validation. In most patients reported by Di Bella et al., disease onset was estimated during adolescence (between 10 to 20 years of age) with mainly poor school performance and walking difficulties. At examination (between 21 to 57 years of age), patients exhibited spastic paraplegia - sometimes associated with cerebellar ataxia or dystonia -, and various degrees of cognitive impairment. 
Pathogenic variants in $P L P 1$, encoding the most predominant myelin protein, are the first cause of hypomyelinating leukodystrophies in children. In adults, $P L P 1$ pathogenic variants can cause spastic paraplegia type 2, mostly in women - e.g. mothers of boys presenting with a severe hypomyelinating disease -, concordant with the X-linked inheritance of this disease. Brain MRI usually shows mild white matter abnormalities, sometimes mimicking MS ${ }^{4}$. Both GJC2 and GJA1 encode connexins $(\mathrm{Cx})-\mathrm{Cx} 47$ and $\mathrm{Cx} 43$, respectively. $\mathrm{Cx} 47$ is expressed in oligodendrocytes while $\mathrm{Cx} 43$ is expressed in astrocytes and plays a role in astrocyte-oligodendrocyte communication by heterotypic $\mathrm{Cx} 43 / \mathrm{Cx} 47$ channels. Unlike GJC2 variants inherited in a recessive manner and manifesting mainly in children, GJA1 variants follow a dominant pattern and present with adult-onset spastic paraplegia, hypomyelination and recognizable skeletal abnormalities (i.e. oculo-dento-digital dysplasia). Few patients with $G J C 2$ pathogenic variants have been reported with an adult-onset cerebellar ataxia and mild brain hypomyelination ${ }^{5}$. TUBB $4 A$ is associated with two different clinical conditions, dystonia type 4 (DYT4) and hypomyelination with atrophy of the basal ganglia and cerebellum $(\mathrm{H}-\mathrm{ABC})$. Isolated hypomyelination has also been observed in few patients with adolescent-onset spastic paraplegia ${ }^{6}$. Pathogenic variants in POLR genes (POLR3A, POLR3B, POLRIC, POLR $3 K$ ) cause abnormal messenger RNA translation and hypomyelination. POLR $3 A$ has been reported with a spectrum of diseases ranging from $4 \mathrm{H}$ (hypomyelination, hypodontia, hypogonadotropic hypogonadism), spastic ataxia and normal myelination, to, rarely, adult-onset cerebellar ataxia and hypomyelination ${ }^{7}$. Di Bella et al. report the first patients bearing POLRIC and RARS1 pathogenic variants with adult-onset spastic paraplegia, cognitive decline and hypomyelination 3. The identification in 2 patients of variants in genes (PEX3 and PEX13) encoding peroxins - i.e. proteins involved in peroxisome biogenesis - is also noteworthy ${ }^{3}$. Late-onset, sometimes adult-onset, forms of peroxisome biogenesis disorders (PBD) are increasingly identified with NGS. Additionally, children with PBD often present with white matter abnormalities. However, Di Bella et al. did not perform biochemical studies to support the pathogenicity of their variants. Furthermore, the matter abnormalities presented by their patients may not be related to primary but secondary hypomyelination due to neuronal degeneration ${ }^{1}$.

Overall, the work from Di Bella et al. presenting the largest series of patients with hypomyelinating disorders stresses out the importance of recognizing such MRI phenotypes in adult patients with motor and cognitive decline. Like other inherited disorders, phenotypic severity and age of onset of leukodystrophies may be modulated by genetic, environmental and ontogenic factors ${ }^{8}$. Considering the limitations of NGS as a stand-alone test, especially for variants of unknown significance or when the segregations of variants cannot be established in adult patients (with deceased parents), the diagnostic process of leukodystrophies in adults should start with in-depth MRI pattern recognition ${ }^{1}$, which helps distinguishing between genetic and acquired diseases and may allow a specific diagnosis or short differential diagnosis containing only a few genes such as hypomyelination. 


\section{References}

1. van der Knaap MS, Schiffmann R, Mochel F, Wolf NI. Diagnosis, prognosis, and treatment of leukodystrophies. Lancet Neurol. 2019;18(10):962-972. doi: 10.1016/S1474-4422(19)30143-7.

2. Lynch DS, Wade C, Paiva ARB, et al. Practical approach to the diagnosis of adult-onset leukodystrophies: an updated guide in the genomic era. J Neurol Neurosurg Psychiatry. 2019;90(5):543-554. doi: 10.1136/jnnp-2018-319481.

3. Di Bella D, Magri S, Benzoni C, et al. Hypomyelinating leukodystrophies in adults: Clinical and genetic features. Eur J Neurol. 2020 Nov 15. doi: 10.1111/ene.14646.

4. Rubegni A, Battisti C, Tessa A, et al. SPG2 mimicking multiple sclerosis in a family identified using next generation sequencing. $J$ Neurol Sci. 2017 ;375:198-202. doi: 10.1016/j.jns.2017.01.069.

5. Kuipers DJS, Tufekcioglu Z, Bilgiç B, et al. Late-onset phenotype associated with a homozygous GJC2 missense mutation in a Turkish family. Parkinsonism Relat Disord. 2019; 66:228-231. doi: 10.1016/j.parkreldis.2019.07.033.

6. Lu Y, Ondo Y, Shimojima K, Osaka H, Yamamoto T. A novel TUBB4A mutation G96R identified in a patient with hypomyelinating leukodystrophy onset beyond adolescence. Hum Genome Var. 2017; 4:17035. doi: 10.1038/hgv.2017.35.

7. Yang YM, Zhao ZM, Jia YL, Jia YJ, Han N, Wang JH. A 42-year-old woman with 4H leukodystrophy caused by a homozygous mutation in POLR3A gene. Chin Med J (Engl). 2019;132(15):1879-1880. doi: 10.1097/CM9.0000000000000328.

8. Saudubray JM, Mochel F. The phenotype of adult versus pediatric patients with inborn errors of metabolism. $J$ Inherit Metab Dis. 2018;41(5):753-756. doi: 10.1007/s10545-018-0209-9. 